\title{
ANALISIS FAKTOR YANG MEMPENGARUHI KONSUMEN DALAM PEMBELIAN KERIPIK SINGKONG
}

\author{
Evi Yulia \\ Program studi ekonomi Universitas Islam Lamongan \\ eviyulia@unisla.ac.id \\ Edie Sugiarto \\ Program studi ekonomi Universitas Islam Lamongan \\ ediesugiarto1@gmail.com
}

\begin{abstract}
Abstrak
Prilaku konsumen sangat penting dipelajari oleh banyak masyarakat atau perusahaan diseluru dunia, prilaku konsumen sangat menentukan kemajuan perusahaan, dengan mengetahui prilaku konsumen maka perusahaan dapat menentukan strategi dan konsep untuk memuaskan konsumen, ada banyak faktor faktor yang mempengaruhi prilaku konsumen dalam keputusan pembelian. Demi kesuksesan dan kemajuan perusahaan maka Perusahaan perlu mengetahui faktorfaktor yang mempengaruhi konsumen dalam keputusan pembelian. Tujuan penelitian ini adalah untuk mengetahui faktor-faktor yang mempengaruhi konsumen dalam melakakukan pembelian keripik singkong dan dapat bermanfaat bagi para peneliti dalam melakukan penelitian dan pengembangan ilmu pengetahuan dan teknologi.

Metode yang digunakan dalam penelitian ini adalah uji validitas, realibitas, regresi liner berganda dan melakukan analisis faktor tehadap ketiga variabel yaitu variabel individual terdiri dari Sembilan belas sub variabel, variabel lingkungan terdiri dariempat belas sub variabel, dan variabel marketing strategy terdiri dari empat belas sub variabel. Selanjutnya empat puluh tujuh sub variabel akan dianalisis menggunakan analisis factor

Berdasarkan hasil penelitian faktor-faktor yang mempengaruhi konsumen dalam pembelian keripik singkong adalah individual, lingkungan dan marketing strategy. Dari hasil penelitian Terbentu lima faktor dari Variabel individual yaitu Faktor persepsi merk, Faktor gaya hidup, Faktor demografi konsumen, Faktor personalia dan faktor kebutuhan dan keinginan konsumen. Terbentuk empat faktor dari Variabel Lingkungan yaitu Faktor situasional, Faktor budaya, Faktor grup tatap muka, dan Faktor social. Terbentuk tiga faktor dari variabel Marketing startegy yaitu Faktor promosi, faktor, produk dan faktor distribusi Berdasarkan penelitian menggunakan total nilai varians pada total variance explaine, factor yang paling dominan mempengaruhi keputusan pembelian keripik singkong adalah faktor promosi dengan nilai varian paling besar dan tertinggi. Ternyata Penelitian ini sangat bermanfaat dalam pengemabngan ilmu pengetahuan dan tekhnologi, dengan mengetahui faktor-faktor yang mempengaruhi konsumen maka tekhnologi baru akan diciptakan menyesuaikan selera konsumen.
\end{abstract}

Kata kunci: Perilaku Konsumen, Analisis Faktor, Keripik Singkong. 


\section{PENDAHULUAN}

Indonesia merupakan negara agraris yang memiliki sumber daya alam yang berlimpah dan lahan yang luas untuk penunjang kegiatan pertanian. Hasilpertanian pangan ke tiga terbesar setelah padi dan jagung yaitu singkong,sehingga singkong mempunyai potensi sebagai bahan baku yang penting bagiberbagai produk pangan dan industri. Menurut data BPS (Badan Pusat Statistika,2015) produksi singkong di Indonesia sebesar 21.790.956 ton, sedangkan untuk diwilayah Jawa Timur, produksi singkong sebesar 3.161.573 ton.

Singkong merupakan hasil pertanian yang cocok untuk dijadikan bisnisyang cukup besar. Dengan mengetahui pemanfaatan dan produkproduk apa sajayang dapat dihasilkan dari singkong tentu akan mendorong dan memotivasi petaniuntuk memanfaatkan hasil pertaniannya agar memperoleh penghasilan yang lebihtinggi. Singkong dapat diolah menjadi berbagai jenis makanan yang enak dan jugabernilai gizi tinggi. Salah satu pemanfaatan singkong yaitu keripik singkong.Keripik singkong merupakan produk makanan ringan yang banyak digemari olehmasyarakat umum dari kalangan anak-anak sampai orang tua baik golongaanmasyarakat bawah maupun kalangan atas (Umikalsum, 2015).

Salah satu usaha pengolahan keripik singkong di Lamongan adalah UD Barokah. Camilan ini sudah dipasarkan di wilayah Mantup dan Kota Lamongan. Peluang usaha keripik singkong sendiri mempunyai prospek yang cerah jika pengelolaannya dijalankan dengan baik, karena mudah tersedia di warung, toko, dan supermarket. Harganya terjangkau dan praktis serta kualitas yang lebih baik dengan rasa yang renyah dan gurih, keripik singkong bisa juga dijadikan sebagai oleh-oleh.
Adanya berbagai macam merek keripik singkong yang ditawarkan dipasaran tentunya membuat konsumen dihadapkan dengan berbagai alternatif yangada sehingga konsumen cenderung mempunyai preferensi tertentu sebelummelakukan proses pengambilan keputusan. Kegunaan preferensi konsumen terhadap barang atau jasa adalah untuk mengetahui apakah barang atau jasa tersebut sesuai dengan yang diinginkan konsumen selama ini. Oleh karena itu, para produsen keripik singkong harus mampu merumuskan strategi yang tepat untuk menghadapi persaingan sehingga mampu bertahan dalam industri keripik singkong.

Rumusan masalah dalam penelitian ini adalah apakah faktorfaktor yang mempengaruhi konsumen dalam melakakukan pembelian keripik singkong. (b) Apakah penelitian ini bermanfaat bagi para peneliti dalam melakukan penelitian dan pengembangan ilmu pengetahuan dan teknologi

Tujuan Penelitian ini adalah (a) Untuk Mengetahui faktor-faktor yang mempengaruhi konsumen dalam melakakukan pembelian keripik singkong. (b) Dapat bermanfaat bagi para peneliti dalam melakukan penelitian dan pengembangan ilmu pengetahuan dan teknologi.

\section{TINJAUAN PUSTAKA}

Berdasarkan Badan Litbang Pertanian (2011) Singkong atau ubi kayu (Manihot esculenta Crantz) merupakan salah satu sumber karbohidrat lokal Indonesia yang menduduki urutan ketiga terbesar setelah padi dan jagung. Tanaman ini merupakan bahan baku yang paling potensial untuk diolah menjadi tepung. Untuk olahan langsung, sebaiknya digunakan bahan baku singkong yang tidak pahit. Beberapa jenis olahan singkong saat ini menjadi bisnis yang 
menguntungkan, seperti keripik berbumbu dengan berbagai merek: Qtela, Kusuka, Maici dan jenis keripik balado. Berbagai jenis olahan langsung dengan bahan baku singkong telah berkembang menjadi industri skala besar, menengah dan rumah tangga.

Ada dua jenis singkong, yaitu singkong yang berdaging putih dan singkong yang berdaging kuning. Singkong yang berdaging kuning biasanya lebih halus tanpa terdapat serat- serat yang kasar sehingga rasanya lebih enak dibandingkan dengan singkong yang berdaging putih (Rahma, 2010). Singkong kuning (singkong mentega) jika dimasak memliki tekstur yang pulen dan cenderung lembut layaknya mentega. Singkong ini cocok untuk dibuat penganan singkong yang dihaluskan misalnya comro, getuk, ketimus, atau singkong goreng. Singkong kuning tidak cocok untuk dibuat keripik karena keripik sulit mengering. Jika akan digoreng, singkong ini lebih baik direbus dahulu bersama bumbu hingga matang dan sedikit pecah, baru digoreng dengan minyak panas. Sedangkan singkong putih lebih cocok untuk membuat keripik, karena teksturnya lebih padat dan keras. Singkong yang baik memiliki penampakan yang mulus, tidak terlalu banyak akarnya, tidak berwarna kebiruan dan tidak kering di bagian luarnya, juga tidak banyak luka pada kulitnya. Keripik singkong merupakan sejenis makanan ringan berupa irisan tipis dari umbi umbian yang mengandung pati. Biasanya keripik singkong melalui tahap penggorengan, tetapi ada pula yang hanya melalui penjemuran, atau pengeringan. Keripik singkong dapat berasa dominan asin, pedas, manis, asam, gurih, atau paduan dari semuanya.

Pemasaran merupakan suatu proses sosial dan manajerial di mana individudan kelompok menciptakan, menawarkan dan bertukar sesuatu yang bernilai satusama lain untuk mendapatkan kebutuhan dan keinginan mereka. Konsep intipemasaran terdiri dari (1) kebutuhan, keinginan dan permintaan. (2) produk nilai, biaya, dankepuasan. (3) Pertukaran , transaksi, dan hubungan. (4) pasar dan pemasaran sertapemasar (Abdullah \& Tantri, 2012). Sedangkan menurut Kotler dan Garry (2003), pemasaran sebagai proses sosial dan manajerial di mana individu atau kelompok untuk memperoleh apa yang mereka butuhkan dan inginkan melalui penciptaan dan pertukaran produk erta nilai dengan pihak lain. Tujuan yang ingin dicapai dari kegiatan ini adalah untuk mendapatkan nilai keuntungan yang optimal atas produk atau jasa yang dihasilkan berkaitan dengan pemenuhan kepuasan bagi konsumen yang menggunakannya. Untuk dapat tercapainya tujuan ini, maka individu atau perusahaan harus dapat menentukan bentuk produk atau jasa seperti apa yang dapat memberikan nilai kepuasan dari keinginan dan kebutuhan konsumen yang dituju dengan cara-cara yang lebih efektif dan efisien dari pada pesaing.

Menurut Wardana (2011), Perilaku konsumen merupakan suatu tindakannyata konsumen yang dipengaruhi oleh faktor pikiran atau minat atau faktor luarlainnya yang mengarahkan mereka untuk memilih dan mempergunakan barang/jasa yang diinginkannya. Faktor yang mempengaruhi pilihan konsumen yaitu (1) Konsumen individu, pilihan merk dipengaruhi oleh (a) Kebutuhan konsumen. (b) Persepsi atas karateristik merk, dan (c) Sikap kearah pilihan. Sebagai tambahan, pilihan merk dipengaruhi oleh demografi konsumen, gaya hidup, dan karekteristik personalia. (2) Pengaruh lingkungan, lingkungan pembelian konsumen ditunjukkan oleh (a) Budaya 
(Norma kemasyaratan, pengaruh kedaerahan atau kesukuan) (b) Kelas sosial (keluasan grup sosial ekonomi atas harta milik konsumen) (c) Grup tata muka (teman, anggota keluarga, dan grup referensi) dan (d) Faktor menentukan yang situasional (situasi dimana produk dibeli sepertikeluarga yang menggunakan mobil dan kalangan usaha) (3)Marketing strategy Merupakan variabel dimana pemasar mengendalikan usahanya dalam memberitahu dan mempengaruhi konsumen. Variabel-variabelnya adalah (a) Barang (b) Harga (c) Periklanan (d) Distribusi

Kerangka berfikir dalam penelitian ini adalah

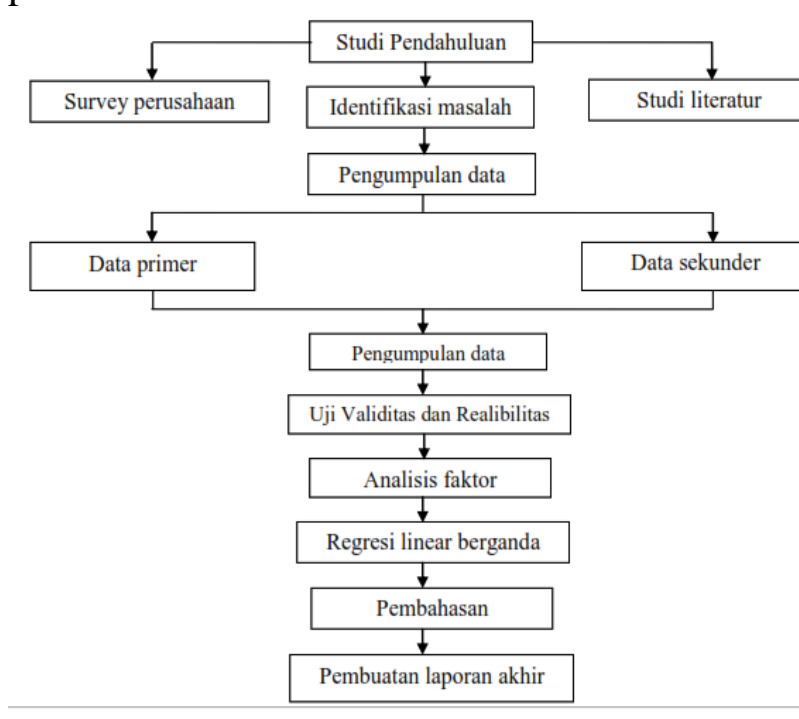

\section{METODE PENELITIAN}

Dalam penelitian ini populasi yang digunakan adalah Populasi menurut Santoso dan Tjiptono didalam $\mathrm{M}$. Hariwijaya (2008:35), menjelaskan bahwa populasi merupakan sekumpulan orang atau objek yang memiliki kesamaan dalam satu atau beberapa hal dan yang, membentuk masalah pokok dalam suatu riset khusus, dalam hal ini populasi yang diteliti terdefinisikan dengan jelas. Populasi dalam penelitian ini adalah masyarakat kecamatan Mantup.

Sampel adalah bagian dari jumlah populasi yang ada, menurut
Santoso dan Tjiptono, didalam M Hari yaya (2008:56), menjelaskan bahwa sampel adalah semacam miniatur dari populasinya. Dalam pengambilan sampel untuk sebuah penelitian dapat digunakan kuesioner, untuk memperoleh tanggapan dari konsumen yang masuk dalam sampel yang diteliti. Sampel yang digunakan dalam penelitian ini sebanyak 100 sampel responden.

Pengambilan sampel dalam penelitian ini menggunakan teknik pengambilan sampel dari suatu populasi berdasarkan kriteria tertentu (Purposive Sampling). Teknik sampling ini termasuk dalam NonProbability Sample yaitu teknik pengambilan sampel yang tidak memberi peluang/kesempatan sama bagi setiap unsur atau anggota populasi untuk dipilih menjadi sampel (Sugiyono, 2012). Hal ini menunjukkan bahwa setiap sampel yang diambil untuk mengisi kuesioneradalah orang yang benarbenar membeli produk olahan singkong karena untuk mendapatkan jawaban yang valid.

Data yang digunakan dalam penelitian ini berbentuk data primer dan data sekunder. Data primer dalam penelitian ini adalah data jumlah penduduk mantup. Sedangkan data skunder adalah data responden, data survey penelitian atau data hasil kuisioner

Operasional variabel yang digunakan dalam penelitian ini ada 3 variabel $X$ yang terdiri dari sub-sub variabel dan 1 Variabel $Y$. Variabel $\mathrm{X}_{1}$ yaitu Variabel individual yang terdiri dari $\mathrm{X}_{1.1}$ kebutuhan dan keinginan konsumen, $\mathrm{X}_{1.2}$ pembelian keripik singkong berdasarkan merk-merk tertentu, $\mathrm{X}_{1.3}$ merk sudah dikenal konsumen, $\mathrm{X}_{1.4}$ kepercayaan terhadap merk, $\mathrm{X}_{1.5}$ merk berkualitas, $\mathrm{X}_{1.6}$ usia konsumen, $\mathrm{X}_{1.7}$ status konsumen, $\mathrm{X}_{1.8}$ perbedaan profesi, $\mathrm{X}_{1.9}$ konsumen 
berpendapatan rendah, $\mathrm{X}_{1.10}$ konsumen berpendapatan tinggi, $\mathrm{X}_{1.11}$ konsumen berpendidikan tinggi, $\mathrm{X}_{1.12}$ Konsumen berpendidikan rendah, $\mathrm{X}_{1.13}$ konsumen beragama islam, $\mathrm{X}_{1.14}$ Pengalaman konsumen, $\mathrm{X}_{1.15}$ Keinginan pribadi konsumen, $\mathrm{X}_{1.16}$ dorongan diri dalam mengkonsumsi keripik singkong, $\mathrm{X}_{1.17}$ gaya hidup sehat, $\mathrm{X}_{1.18}$ gaya hidup modern, $\mathrm{X}_{1.19}$ gaya hidup hemat

Variabel $\mathrm{X}_{2}$ yaitu variabel Lingkungan yang terdiri dari $\mathrm{X}_{2.1}$ Kebiasaan masyarakat, $\mathrm{X}_{2.2}$ Tradisi masyarakat, $X_{2.3}$ Makanan camilan kelas ekonomi menengah bawah, $\mathrm{X}_{2.4}$ Makanan camilan kelas ekonomi menengah atas, $\mathrm{X}_{2.5}$ Kelas social lebih tinggi, $\mathrm{X}_{2.6}$ Keluarga sebagai refrensi, $\mathrm{X}_{2.7}$ rekan kerja sebagai refrensi, $\mathrm{X}_{2.8}$ Rekan sekomunitas sebagai refrensi, $\mathrm{X}_{2.9}$ Keripik singkong dibeli saat acara tertentu, $\mathrm{X}_{2.10}$ Keripik singkong dibeli untuk oleh-oleh saat berlibur, $\mathrm{X}_{2.11}$ pembelian keripik singkong diwaktu senja hari, $\mathrm{X}_{2.12}$ pembelian keripik singkong diwaktu pagi hari, $\mathrm{X}_{2.13}$ pembelian keripik singkong saat kondisi senang, $\mathrm{X}_{2.14}$ pembelian keripik singkong saat kondisi sedih atau kecewa

Variabel $\mathrm{X}_{3}$ yaitu variabel Marketing strategy terdiri dari $\mathrm{X}_{3.1}$ keripik singkong memiliki cita rasa yang khas dan gurih, $\mathrm{X}_{3.2}$ Camilan tahan lama dan tiddak mudah basi, $\mathrm{X}_{3.3}$ Tekstur keripik singkong gurih dan renyah, $\mathrm{X}_{3.4}$ Makanan camilan saat santai bersama keluarga, $\mathrm{X}_{3.5}$ Desaign produk menarik, $\mathrm{X}_{3.6}$ Varian rasa yang ditawarkan berbeda-beda, $\mathrm{X}_{3.7}$ Harga sesuai pasaran, $\mathrm{X}_{3.8}$ Harga murah dan terjangkau, $\mathrm{X}_{3.9}$ promosi dari mulut ke mulut, $X_{3.10}$ promosi dilakukan melalui $\mathrm{TV}$ dan radio, $\mathrm{X}_{3.11}$ promosi secara online, $\mathrm{X}_{3.12}$ keripik mudah diperoleh, $\mathrm{X}_{3.13}$ lokasi penjualan dekat dengan rumah, $\mathrm{X}_{3.14}$ pembelian dilakukan ditempat lain karena harga yang ditawarkan lebih murah. Sedangkan dalam penelitian yang termasuk Variabel Y yaitu Keputusan Pembelian.

Setelah data diperoleh, maka dilakukan uji validitas dan reliabilitas dengan menggunakan software computer yaitu SPSS dengan tujuan untuk memudahkan penulis dalam menganalisis data.(1) Uji Validitas Menurut Ghozali (2013), uji validitas digunakan untuk mengukur valid tidaknya suatu kuesioner. Suatu kuesioner dikatakan valid jika pertanyaan pada kuesioner mampu untuk mengungkapkan sesuatu yang akan diukur oleh kuesioner tersebut. Uji validitas dilakukan dengan cara menguji korelasi antara skor item dengan skor total. Dalam hal ini koefisien korelasi yang tinggi menunjukkan bahwa item-item tersebut dapat mengungkapkan indikator yang akan diukur. Kriteria pengujian validitas instrumen indikator penelitian adalah (a) Jika $r$ hitung lebih besar dari $r$ tabel (pada taraf signifikansi 0,05 atau 5 persen), maka kuesioner tersebut valid. (b) Jika $r$ hitung lebih kecil dari $\mathrm{r}$ tabel (pada taraf signifikansi 0,05 atau 5 persen), maka kuesioner tersebut tidak valid (2) Uji Reabilitas Menurut Ghozali (2013), uji reliabilitas digunakan untuk mengukur suatu kuesioner yang merupakan indikator dari variabel. Suatu kuesioner dikatakan reliabel jika jawaban seseorang terhadap pertanyaan adalah konsisten atau stabil dari waktu ke waktu. Untuk menguji reliabilitas sampel maka akan digunakan tes kehandalan "Cronbach Alpha" yang akan menunjukkan ada tidaknya konsistensi antara pertanyaan dan sub bagian bagian kelompok pertanyaan. Suatu konstruk atau variabel dapat dikatakan reliabel jika memberikan nilai Cronbach Alpha lebih besar dari 0,6. 
Analisis data yang digunakan factor. Data yang diperoleh dari hasil wawancara menggunakan kuesioner, kemudian ditabulasi kedalam Microsoft Excel. Setelah itu data tersebut dilakukan uji validitas dan reabilitas menggunakan SPSS 16.0. untuk mengetahui valid tidaknya suatu data dan untuk mengetahui reliabel atau nyata tidaknya suatu data. Kemudian dianalisis menggunakan analisis faktor yang ada dalam software SPSS untuk memudahkan peneliti dalam menganalisis data sehingga nanti output nyata dari analisis faktor ini adalah faktor yang paling dominan yang mempengaruhi pembelian keripik singkong.

Menurut Sarjono \& Julianita (2011), analisis regresi berganda merupakan analisis yang mengukur pengaruh variabel bebas terhadap variabel terikat. Dimana variabel bebasnya $(\mathrm{X})$ terdiri dari tiga variabel, untuk variabel terikatnya hanya terdiri satu variabel saja (Y). Adapun rumus umum dalam regresi linear berganda adalah sebagai berikut:

\section{HASIL PENELITIAN DAN PEMBAHASAN}

Berikut ini hasil dari penelitian tentang uji validitas diambil dari data yang melalui SPSS.

\section{Tabel 5.60}

Hasil Analisis uji validitas variable individual $\left(X_{1}\right)$ dalam penelitian ini adalah analisis

$\begin{array}{cccc}\mathrm{X}_{1.11} & 0,586 & 0,1966 & \text { Valid } \\ \mathrm{X}_{1.12} & 0,364 & 0,1966 & \text { Valid } \\ \mathrm{X}_{1.13} & 0,521 & 0,1966 & \text { Valid } \\ \mathrm{X}_{1.14} & 0,645 & 0,1966 & \text { Valid } \\ \mathrm{X}_{1.15} & 0,339 & 0,1966 & \text { Valid } \\ \mathrm{X}_{1.16} & 0,597 & 0,1966 & \text { Valid } \\ \mathrm{X}_{1.17} & 0,637 & 0,1966 & \text { Valid } \\ \mathrm{X}_{1.18} & 0,545 & 0,1966 & \text { Valid } \\ \mathrm{X}_{1.19} & 0,489 & 0,1966 & \text { Valid } \\ & \text { Suatu } & \text { instrumen } & \text { dikatakan }\end{array}$

Valid apabila $r_{\text {hitung }}>r_{\text {tabel }}$, Dari hasil Uji Validitas instrumen Variabel $\left(\mathrm{X}_{1}\right)$ didapatkan $r_{\text {hitung }}>r_{\text {tabel }}$, jadi seluruh butir pernyataan dari variabel $\left(\mathrm{X}_{1}\right)$ independen terbukti valid.

\section{Tabel 5.62}

Hasil Analisis uji validitas variable Lingkungan $\left(\mathrm{X}_{2}\right)$

\begin{tabular}{crrc}
\hline Item & r hitung & r tabel & Keterangan \\
\hline X.2.1 & 0,356 & 0,1966 & Valid \\
X.2.2 & 0,378 & 0,1966 & Valid \\
X.2.3 & 0,309 & 0,1966 & Valid \\
X.2.4 & 0,614 & 0,1966 & Valid \\
X.2.5 & 0,510 & 0,1966 & Valid \\
X.2.6 & 0,437 & 0,1966 & Valid \\
X.2.7 & 0,598 & 0,1966 & Valid \\
X.2.8 & 0,557 & 0,1966 & Valid \\
X.2.9 & 0,631 & 0,1966 & Valid \\
X.2.10 & 0,512 & 0,1966 & Valid \\
X.2.11 & 0,488 & 0,1966 & Valid \\
gaX.2.12 & 0,436 & 0,1966 & Valid \\
X.2.13 & 0,437 & 0,1966 & Valid \\
X.2.14 & 0,585 & 0,1966 & Valid
\end{tabular}

\begin{tabular}{|c|c|c|c|c|c|}
\hline Item & r hitung & $\mathrm{r}$ tabel & KeterangaX. & 0,436 & 0,1966 \\
\hline $\mathrm{X}_{1.1}$ & 0,208 & 0,1966 & Valid X.2.13 & 0,437 & 0,1966 \\
\hline $\mathrm{X}_{1.2}$ & 0,387 & 0,1966 & Valid X.2.14 & 0,585 & 0,1966 \\
\hline $\mathrm{X}_{1.3}$ & 0,641 & 0,1966 & Valid & & \\
\hline $\mathrm{X}_{1.4}$ & 0,436 & 0,1966 & Valid Sumbe & \multirow{3}{*}{\multicolumn{2}{|c|}{$\begin{array}{l}\text { Sumber : Data diolah Tahun } 2018 \\
\text { Suatu instrumen dikatakan } \\
\text { Valid apabila } r_{\text {hitung }}>r_{\text {tabel }} \text {, Dari hasil Uji }\end{array}$}} \\
\hline $\mathrm{X}_{1.5}$ & 0,393 & 0,1966 & Valid & & \\
\hline $\mathrm{X}_{1.6}$ & 0,433 & 0,1966 & Valid Valid a & & \\
\hline $\mathrm{X}_{1.7}$ & 0,353 & 0,1966 & \multirow{3}{*}{\multicolumn{3}{|c|}{$\begin{array}{l}\text { Validitas instrumen Variabel }\left(\mathrm{X}_{2}\right) \\
\text { didapatkan } \mathrm{r}_{\text {hitung }}>\mathrm{r}_{\text {tabel }} \text {, jadi seluruh } \\
\text { butir pernyataan dari variabel }\left(\mathrm{X}_{2}\right)\end{array}$}} \\
\hline $\mathrm{X}_{1.8}$ & 0,483 & 0,1966 & & & \\
\hline $\mathrm{X}_{1.9}$ & 0,374 & 0,1966 & Valid butir $\mathrm{p}$ & & \\
\hline $\mathrm{X}_{1.10}$ & 0,487 & 0,1966 & Valid indep & ukti v & \\
\hline
\end{tabular}


koefisien regresi negatif. Hal tersebut menunjukkan factor individual (b1) dan factor marketing strategy (b3) memiliki pengaruh secara positif terhadap keputusan pembelian keripik singkong sedangkan factor lingkungan memiliki pengaruh negative terhadap keputusan pembelian yang artinya factor lingkungan tidak memiliki pengaruh terhadap keputusan pembelian keripik singkong

Nilai KMO dan Bartlett Test untuk Variabel individual

Tabel 5.69

KMO and Bartlett's Test

\begin{tabular}{|cl|r|}
\hline \multicolumn{2}{|l|}{ Kaiser-Meyer-Olkin Measure of } \\
Sampling Adequacy. & Approx. Chi- \\
Bartlett's Test of & Square & 694,607 \\
Sphericity & Df & 171 \\
& Sig. &, 000 \\
& & \\
\hline
\end{tabular}

Dari tabel hasil nilai output diatas dapat dilihat bahwa nilai KMO dan Bartlett Test menunjukkan nilai 0,774 dengan tingkat signifikan 0,000 oleh sebab itu maka variable-variabel yang digunakan saling berkorelasi dan dapat dianalisis lebih lanjut

Sesudah variable diuji dan menghasilkan nilai yang mencukupi, tahap selanjutnya adalah melakukan proses inti dari analisis factor yaitu melakukan ekstraksi terhadap sekumpulan variable yang sudah ada, sehingga terbentuk satu atau beberapa factor. Metode yang digunakan dalam ekstraksi ini adalah principal component analysis untuk mengetahui dari sekian variable yang akan masuk dalam factor mana, maka dilakukan proses rotasi dengan menggunakan metode varimax (bagian dari ortogonal)

Tabel. $\mathbf{5 . 7 0}$

(a) Variabel individual $\left(\mathrm{X}_{1}\right)$ dengan indicator kebutuhan dan keinginan konsumen $\left(\mathrm{X}_{1.1}\right)$ menunjukkan nilai 0,798 hal ini menunjukkan bahwa 79,8 persen varians dari kebutuhan dan keinginan konsumen $\left(\mathrm{X}_{1.1}\right)$ dapat dijelaskan, oleh factor yang terbentuk (b) Variabel individual $\left(\mathrm{X}_{1}\right)$ dengan indicator persepsi merk tentang pembelian keripik singkong berdasarkan merk-merk terntentu $\left(\mathrm{X}_{1.2}\right)$ menunjukkan nilai 0,552 hal ini menunjukkan bahwa 55,2 persen varians dari pembelian keripik singkong berdasarkan merk-merk terntentu $\left(\mathrm{X}_{1.2}\right)$ dapat dijelaskan, oleh factor yang terbentuk (c) Variabel individual $\left(\mathrm{X}_{1}\right)$ dengan indicator persepsi merk tentang merk yang sudah dikenal $\left(\mathrm{X}_{1.3}\right)$ menunjukkan nilai 0,687 hal ini menunjukkan bahwa 68.7 persen varians dari merk yang sudah dikenal $\left(\mathrm{X}_{1.3}\right)$ dapat dijelaskan, oleh factor yang terbentuk (d) Variabel 
individual $\left(\mathrm{X}_{1}\right)$ dengan indicator persepsi merk tentang kepercayaan merk $\left(\mathrm{X}_{1.4}\right)$ menunjukkan nilai 0,419 hal ini menunjukkan bahwa 41,9 persen varians dari kepercayaan merk $\left(\mathrm{X}_{1.4}\right)$ dapat dijelaskan, oleh factor yang terbentuk (e) Variabel individual $\left(\mathrm{X}_{1}\right)$ dengan indicator persepsi merk tentang merk berkualitas $\left(\mathrm{X}_{1.5}\right)$ menunjukkan nilai 0,660 hal ini menunjukkan bahwa 66,0 persen varians dari merk berkualitas $\left(\mathrm{X}_{1.5}\right)$ dapat dijelaskan, oleh factor yang terbentuk (f) Variabel individual $\left(\mathrm{X}_{1}\right)$ dengan indicator Demografi konsumen tentang usia konsumen $\left(\mathrm{X}_{1.6}\right)$ menunjukkan nilai 0,502 hal ini menunjukkan bahwa 50,2 persen varians dari usia konsumen $\left(\mathrm{X}_{1.6}\right)$ dapat dijelaskan, oleh factor yang terbentuk $(\mathrm{g})$ Variabel individual $\left(\mathrm{X}_{1}\right)$ dengan indicator Demografi konsumen tentang status konsumen $\left(\mathrm{X}_{1.7}\right)$ menunjukkan nilai 0,712 hal ini menunjukkan bahwa 71,2 persen varians dari konsumen status konsumen $\left(\mathrm{X}_{1.7}\right)$ dapat dijelaskan, oleh factor yang terbentuk (h) Variabel individual $\left(\mathrm{X}_{1}\right)$ dengan indicator Demografi konsumen tentang perbedaan profesi pekerjaan $\left(\mathrm{X}_{1.8}\right)$ menunjukkan nilai 0,654 hal ini menunjukkan bahwa 65,4 persen varians dari perbedaan profesi pekerjaan $\left(\mathrm{X}_{1.8}\right)$ dapat dijelaskan, oleh factor yang terbentuk (i) Variabel individual $\left(\mathrm{X}_{1}\right)$ dengan indicator Demografi konsumen tentang konsumen berpendapatan rendah $\left(\mathrm{X}_{1.9}\right)$ menunjukkan nilai 0,647 hal ini menunjukkan bahwa 64,7 persen varians dari konsumen berpendapatan rendah $\left(\mathrm{X}_{1.9}\right)$ dapat dijelaskan, oleh factor yang terbentuk (j) Variabel individual $\left(\mathrm{X}_{1}\right)$ dengan indicator Demografi konsumen tentang konsumen berpendapatan tinggi $\left(\mathrm{X}_{1.10}\right)$ menunjukkan nilai 0,664 hal ini menunjukkan bahwa 66,4 persen varians dari konsumen berpendapatan tinggi $\left(\mathrm{X}_{1.10}\right)$ dapat dijelaskan, oleh factor yang terbentuk (k) Variabel individual $\left(\mathrm{X}_{1}\right)$ dengan indicator Demografi konsumen tentang konsumen berpendidikan tinggi $\left(\mathrm{X}_{1.11}\right)$ menunjukkan nilai 0,563 hal ini menunjukkan bahwa 56,3 persen varians dari konsumen berpendidikan tinggi $\left(\mathrm{X}_{1.11}\right)$ dapat dijelaskan, oleh factor yang terbentuk (1) Variabel individual $\left(\mathrm{X}_{1}\right)$ dengan indicator Demografi konsumen tentang konsumen berpendidikan rendah $\left(\mathrm{X}_{1.12}\right)$ menunjukkan nilai 0,684 hal ini menunjukkan bahwa 68,4 persen varians dari konsumen berpendidikan rendah $\left(\mathrm{X}_{1.12}\right)$ dapat dijelaskan, oleh factor yang terbentuk (m) Variabel individual $\left(\mathrm{X}_{1}\right)$ dengan indicator Demografi konsumen tentang konsumen beragama islam $\left(\mathrm{X}_{1.13}\right)$ menunjukkan nilai 0,651 hal ini menunjukkan bahwa 65,1 persen varians dari konsumen beragama islam $\left(\mathrm{X}_{1.13}\right)$ dapat dijelaskan, oleh factor yang terbentuk (n) Variabel individual $\left(\mathrm{X}_{1}\right)$ dengan indicator personalia tentang pengalaman konsumen $\left(\mathrm{X}_{1.14}\right)$ menunjukkan nilai 0,629 hal ini menunjukkan bahwa 62,9 persen varians dari pengalaman konsumen $\left(\mathrm{X}_{1.14}\right)$ dapat dijelaskan, oleh factor yang terbentuk (o) Variabel individual $\left(\mathrm{X}_{1}\right)$ dengan indicator personalia tentang keinginan pribadi $\left(\mathrm{X}_{1.15}\right)$ menunjukkan nilai 0,624 hal ini menunjukkan bahwa 62,4 persen varians dari keinginan pribadi $\left(\mathrm{X}_{1.15}\right)$ dapat dijelaskan, oleh factor yang terbentuk (p) Variabel individual $\left(\mathrm{X}_{1}\right)$ dengan indicator personalia tentang dorongan diri dalam mengkonsumsi keripik singkong $\left(\mathrm{X}_{1.16}\right)$ menunjukkan nilai 0,561 hal ini menunjukkan bahwa 56,1 persen varians dari dorongan diri dalam mengkonsumsi keripik singkong $\left(\mathrm{X}_{1.16}\right)$ dapat dijelaskan, oleh factor yang terbentuk (q) Variabel individual $\left(\mathrm{X}_{1}\right)$ dengan indicator gaya hidup konsumen tentang gaya hidup sehat $\left(\mathrm{X}_{1.17}\right)$ menunjukkan nilai 0,609 hal ini menunjukkan bahwa 60,9 persen varians dari gaya hidup sehat $\left(\mathrm{X}_{1.17}\right)$ 
dapat dijelaskan, oleh factor yang

Tabel 5.72

Component Matrix ${ }^{a}$

\begin{tabular}{|c|c|c|c|c|c|}
\hline & \multicolumn{5}{|c|}{ Component } \\
\hline & 1 & 2 & 3 & 4 & 5 \\
\hline$x 1.1$ & 240, & $\mid-, 042$ & ,318 & 216 & 769 \\
\hline$x 1.2$ & 455, & 028, & 104, & -,557 & 149, \\
\hline$x 1.3$ & 708 & $\mid-, 217$ & -,269 & 231, & 108, \\
\hline x1.4 & 516, & |-,326 & -120 & -,132 & 121, \\
\hline x1.5 & 481, & $\mid-, 644$ &,- 011 &,- 067 &,- 098 \\
\hline x1.6 & 485, & 041, & 486, & -,152 &,- 076 \\
\hline x1.7 & 405, & |-107 & 420, & ,515, &,- 308 \\
\hline x1.8 & ,543, & - -,482 & 266 & 168, &,- 165 \\
\hline x1.9 & 455, & 556, & -279 & 148, & -,175 \\
\hline$\times 1.10$ & ,575, &,- 313 & -278, & 396, & ,042 \\
\hline x1.11 & 663, & $\mid-, 030$ & 135, &,- 315 &,- 062 \\
\hline$x 1.12$ & ,413 & 391 & ,570 & 182 &,- 041 \\
\hline$x 1.13$ & ,611 & ,083 &,- 042 &,- 266 &,- 445 \\
\hline x1.14 & 730, & 157, & -,193 & 070, &,- 172 \\
\hline$\times 1.15$ & 420, & 633, &,- 048 & 183, & 105, \\
\hline x1.16 & 675, & 158, &,- 046 & -260 & 109, \\
\hline$x 1.17$ & ,707 &,- 010 & ,033 &,- 246 & ,218 \\
\hline x1.18 & 626, &,- 006 & -,349 & 140, & 160, \\
\hline$\times 1.19$ & ,552 & 312 &,- 074 & ,084, & 084, \\
\hline
\end{tabular}

Extraction Method: Principal Component

Analysis.

a. 5 components extracted.

terbentuk (r) Variabel individual $\left(\mathrm{X}_{1}\right)$ dengan indicator gaya hidup konsumen tentang gaya hidup modern $\left(\mathrm{X}_{1.18}\right)$ menunjukkan nilai 0,559 hal ini menunjukkan bahwa 55,9 persen varians dari gaya hidup modern $\left(\mathrm{X}_{1.18}\right)$ dapat dijelaskan, oleh factor yang terbentuk (s) Variabel individual $\left(\mathrm{X}_{1}\right)$ dengan indicator gaya hidup tentang gaya hidup hemat $\left(\mathrm{X}_{1.19}\right)$ menunjukkan nilai 0,422 hal ini menunjukkan bahwa 42,2 persen varians dari gaya hdup hemat $\left(\mathrm{X}_{1.19}\right)$ dapat dijelaskan, oleh factor yang terbentuk

Berdasarkan nilai pada tabel communalities bahwa variable-variabel yang ada dapat dijelaskan oleh factor yang terbentuk, semakin besar nilai communalities maka semain erat hubungannya dengan factor yang terbentuk. Untuk menentukan faktor yang terbentuk maka harus dilihat nilai eigenvaluenya harus berada diatas satu (1), jika kurang dari angka 1 maka tidak tepat. Berdasarkan tabel extraction method principal component analysis variable individual hanya 5 faktor yang terbentuk, dimana 5 faktor menunjukkan angka diatas satu dan 14 faktor yang lain menunjukkan angka dibawah 1 . Sehingga untuk variable individual terbatas hanya terdiri dari 5 faktor saja yaitu (a) Factor 1 dengan nilai 5,840 (b) Faktor 2 dengan nilai 1,932 (c) Factor 3 dengan nilai 1,353 (d) Factor 4 dengan nilai 1,324 (e) Factor 5 dengan nilai 1,146

Dari hasil Principal Component Analysis. diatas dapat dianalisis (a) Kebutuhan dan keinginan konsumen $\left(\mathrm{X}_{1.1}\right)$ factor loading yang paling besar berada pada factor ke-5 dengan nilai 0,769 hal ini berarti kebutuhan dan keinginan konsumen $\left(\mathrm{X}_{1.1}\right)$ berada pada factor ke-5 (b) Pembelian keripik singkong berdasarkan merk-merk terntentu $\left(\mathrm{X}_{1.2}\right)$ factor loading yang paling besar berada pada factor ke-1 dengan nilai 0,455 hal ini berarti Pembelian keripik singkong berdasarkan merk-merk tertentu $\left(\mathrm{X}_{1.2}\right)$ berada pada factor ke-1 (c) Merk yang sudah dikenal konsumen $\left(\mathrm{X}_{1.3}\right)$ factor loading yang paling besar berada pada factor ke-1 dengan nilai 0,708 hal ini berarti merk yang sudah dikenal konsumen $\left(\mathrm{X}_{1.3}\right)$ berada pada factor ke-1 (d) Kepercayaan merk $\left(\mathrm{X}_{1.4}\right)$ factor loading yang paling besar berada pada factor ke-1 dengan nilai 0,519 hal ini berarti kepercayaan merk $\left(\mathrm{X}_{1.4}\right)$ berada pada factor Ke- 1 (e) Merk berkualitas $\left(\mathrm{X}_{1.5}\right)$ factor loading yang paling besar berada pada factor ke-1 dengan nilai 0,481 hal ini berarti merk berkualitas 
$\left(\mathrm{X}_{1.5}\right)$ berada pada factor ke-1 (f) Usia konsumen $\left(\mathrm{X}_{1.6}\right)$ factor loading yang paling besar berada pada factor ke-3 dengan nilai 0,486 hal ini berarti usia konsumen $\left(\mathrm{X}_{1.6}\right)$ berada pada factor ke3 (g) Konsumen status konsumen $\left(\mathrm{X}_{1.7}\right)$ factor loading yang paling besar berada pada factor ke-4 dengan nilai 0,515 hal ini berarti status konsumen $\left(\mathrm{X}_{1.7}\right)$ berada pada factor ke-4 Profesi pekerjaan $\left(\mathrm{X}_{1.8}\right)$ factor loading yang paling besar berada pada factor ke-1 dengan nilai 0,543 hal ini berarti profesi pekerjaan $\left(\mathrm{X}_{1.8}\right)$ berada pada factor ke-1 (i) Konsumen berpendapatan rendah $\left(\mathrm{X}_{1.9}\right)$ factor loading yang paling besar berada pada factor ke-2 dengan nilai 0,556 hal ini berarti konsumen berpendapatan rendah $\left(\mathrm{X}_{1.9}\right)$ berada pada factor ke-2 (j) Konsumen berpendapatan tinggi $\left(\mathrm{X}_{1.10}\right)$ factor loading yang paling besar berada pada factor ke-1 dengan nilai 0,575 hal ini berarti konsumen berpendapatan tinggi $\left(\mathrm{X}_{1.10}\right)$ berada pada factor ke-1 (k) Konsumen berpendidikan tinggi $\left(\mathrm{X}_{1.11}\right)$ factor loading yang paling besar berada pada factor ke-1 dengan nilai 0,663 hal ini berarti konsumen berpendidikan tinggi $\left(\mathrm{X}_{1.11}\right)$ berada pada factor ke-1 (1) Konsumen berpendidikan tinggi $\left(\mathrm{X}_{1.12}\right)$ factor loading yang paling besar berada pada factor ke-3 dengan nilai 0,570 hal ini berarti konsumen berpendidikan tinggi $\left(\mathrm{X}_{1.12}\right)$ berada pada factor ke-3 (m) Konsumen beragama islam $\left(\mathrm{X}_{1.13}\right)$ factor loading yang paling besar berada pada factor ke-1 dengan nilai 0,611 hal ini berarti konsumen beragama islam $\left(\mathrm{X}_{1.13}\right)$ berada pada factor ke-1 (n) Pengalaman konsumen $\left(\mathrm{X}_{1.14}\right)$ factor loading yang paling besar berada pada factor ke-1 dengan nilai 0,730 hal ini berarti pengalaman konsumen $\left(\mathrm{X}_{1.14}\right)$ berada pada factor ke-1 (o) Keinginan pribadi $\left(\mathrm{X}_{1.15}\right)$ factor loading yang paling besar berada pada factor ke-2 dengan nilai 0,633 hal ini berarti Keinginan pribadi $\left(\mathrm{X}_{1.15}\right)$ berada pada factor ke-2 (p) Dorongan diri dalam mengkonsumsi keripik singkong $\left(\mathrm{X}_{1.16}\right)$ factor loading yang paling besar berada pada factor ke-1 dengan nilai 0,675 hal ini berarti Dorongan diri dalam mengkonsumsi keripik singkong $\left(\mathrm{X}_{1.16}\right)$ berada pada factor ke-1 (q) Gaya hidup sehat $\left(\mathrm{X}_{1.17}\right)$ factor loading yang paling besar berada pada factor ke-1 dengan nilai 0,707 hal ini berarti gaya hidup sehat $\left(\mathrm{X}_{1.17}\right)$ berada pada factor ke-1 (r) Gaya hidup modern $\left(\mathrm{X}_{1.18}\right)$ factor loading yang paling besar berada pada factor ke-1 dengan nilai 0.626 hal ini berarti gaya hidup modern $\left(\mathrm{X}_{1.18}\right)$ berada pada factor ke-1 (s) Gaya hidup hemat $\left(\mathrm{X}_{1.19}\right)$ factor loading yang paling besar berada pada factor ke-1 dengan nilai 0,552 hal ini berarti gaya hidup hemat $\left(\mathrm{X}_{1.19}\right)$ berada pada factor ke-1

Dari hasil penelitian dan analisis diatas dapat disimpulkan bahwa Faktor factor yang mempengaruhi konsumen dalam melakukan pembelian keripik singkong untuk variabel individual dikelompokkan menjadi 5 (Lima) factor yaitu (1) Faktor 1 dinamakan factor kebutuhan dan keinginan konsumen yang terdiri atas beberapa variabel yaitu $\mathrm{X}_{1.2}$ pembelian keripik singkong berdasarkan merk-merk tertentu $(45,5 \%), \mathrm{X}_{1.3}$ merk sudah dikenal konsumen $(70,8 \%), \quad \mathrm{X}_{1.4}$ kepercayaan terhadap merk $(51,6 \%)$, $\mathrm{X}_{1.5}$ merk berkualitas $(48,1 \%), \mathrm{X}_{1.8}$ perbedaan profesi $(54,3 \%), \quad \mathrm{X}_{1.10}$ konsumen berpendapatan tinggi $(57,5$ $\%), \mathrm{X}_{1.11}$ konsumen berpendidikan tinggi $(66,3 \%), \quad \mathrm{X}_{1.13} \quad$ konsumen beragama islam $(61,1 \%), \quad \mathrm{X}_{1.14}$ pengalaman konsumen (73\%), $\mathrm{X}_{1.16}$ Dorongan diri dalam mengkonsumsi keripik singkong $(67,5 \%), \mathrm{X}_{1.7}$ gaya hidup sehat $(70,7 \%), X_{1.18}$ gaya hidup modern $(62,6 \%)$, dan $\mathrm{X}_{1.19}$ gaya hidup hemat ( 55,2 \%) (2) Faktor 2 dinamakan factor persepsi merk yang terdiri atas dua variabel yaitu $\mathrm{X}_{1.9}$ konsumen berpendapatan rendah $(55,6$ 
\%) dan $\mathrm{X}_{1.15}$ keinginan pribadi $(63,3)$ (3) Faktor 3 dinamakan factor demografi konsumen yang terdiri atas dua variabel yaitu $\mathrm{X}_{1.6}$ usia konsumen $(48,6 \%)$ dan $X_{1.12}$ Konsumen berpendidikan rendah (57 \%) (4) Faktor 4 dinamakan factor gaya hidup yang terdiri atas variabel $\mathrm{X}_{1.7}$ status konsumen $(51,5 \%)$ (5) Faktor 5 dinamakan factor personalia yang terdiri atas variabel $\mathrm{X}_{1.1}$ kebutuhan dan keinginan konsumen $(76,9 \%)$

Variabel Lingkungan (X2) Nilai

KMO dan Bartlett Test untuk Variabel lingkungan

Tabel 5.73

KMO and Bartlett's Test

\begin{tabular}{|c|c|c|}
\hline \multicolumn{2}{|c|}{$\begin{array}{l}\text { Kaiser-Meyer-Olkin Measure of } \\
\text { Sampling Adequacy. }\end{array}$} & ,764 \\
\hline & Approx. Chi- & 454880 \\
\hline Bartlett's Test of & Square & \\
\hline Sphericity & Df & 91 \\
\hline & Sig. &, 000 \\
\hline
\end{tabular}

Dari tabel hasil nilai output diatas dapat dilihat bahwa nilai KMO dan Bartlett Test menunjukkan nilai 0,764 dengan tingkat signifikan 0,000 oleh sebab itu maka variable-variabel yang digunakan saling berkorelasi dan dapat dianalisis lebih lanjut

Tabel 5.74

Communalities

\begin{tabular}{|l|r|r|}
\hline & \multicolumn{1}{|c|}{ Initial } & \multicolumn{1}{|c|}{ Extraction } \\
\hline x2.1 & 1,000 &, 713 \\
x2.2 & 1,000 &, 673 \\
x2.3 & 1,000 &, 610 \\
x2.4 & 1,000 &, 628 \\
x2.5 & 1,000 &, 529 \\
x2.6 & 1,000 &, 615 \\
x2.7 & 1,000 &, 618 \\
x2.8 & 1,000 &, 590 \\
x2.9 & 1,000 &, 650 \\
x2.10 & 1,000 &, 605 \\
x2.11 & 1,000 &, 571 \\
x2.12 & 1,000 &, 677 \\
x2.13 & 1,000 &, 450 \\
x2.14 & 1,000 &, 643 \\
\hline
\end{tabular}

Extraction Method: Principal Component Analysis.
Pada tabel diatas dapat dijelaskan bahwa (a) Variabel Lingkungan $\left(\mathrm{X}_{2}\right)$ dengan indicator budaya tentang pengaruh kebiasaan masyarakat $\left(\mathrm{X}_{2.1}\right)$ menunjukkan nilai 0,713 hal ini menunjukkan bahwa 71,3 persen varians dari pengaruh kebiasaan masyarakat $\left(\mathrm{X}_{2.1}\right)$ dapat dijelaskan, oleh factor yang terbentuk (b) Variabel Lingkungan $\left(\mathrm{X}_{2}\right)$ dengan indicator budaya tentang pengaruh tradisi masyarakat $\left(\mathrm{X}_{2.2}\right)$ menunjukkan nilai 0,673 hal ini menunjukkan bahwa 67,3 persen varians dari pengaruh tradisi masyarakat $\left(\mathrm{X}_{2.2}\right)$ dapat dijelaskan, oleh factor yang terbentuk (c) Variabel Lingkungan $\left(\mathrm{X}_{2}\right)$ dengan indicator kelas sosial tentang Keripik singkong merupakan makanan camilan khas untuk kelas ekonomi menengah bawah $\left(\mathrm{X}_{2.3}\right)$ menunjukkan nilai 0,610 hal ini menunjukkan bahwa 61,0 persen varians dari Keripik singkong merupakan makanan camilan khas untuk kelas ekonomi menengah bawah $\left(\mathrm{X}_{2.3}\right)$ dapat dijelaskan, oleh factor yang terbentuk (d) Variabel Lingkungan $\left(\mathrm{X}_{2}\right)$ dengan indicator kelas sosial tentang Keripik singkong merupakan makanan camilan khas untuk kelas ekonomi menengah atas $\left(\mathrm{X}_{2.4}\right)$ menunjukkan nilai 0,628 hal ini menunjukkan bahwa 62,8 persen varians dari Keripik singkong merupakan makanan camilan khas untuk kelas ekonomi menengah atas $\left(\mathrm{X}_{2.4}\right)$ dapat dijelaskan, oleh factor yang terbentuk (e) Variabel Lingkungan $\left(\mathrm{X}_{2}\right)$ dengan indicator kelas sosial tentang pengaruh kelas social lebih tinggi $\left(\mathrm{X}_{2.5}\right)$ menunjukkan nilai 0,529 hal ini menunjukkan bahwa 52,9 persen varians dari pengaruh kelas social lebih tinggi $\left(\mathrm{X}_{2.5}\right)$ dapat dijelaskan, oleh factor yang terbentuk (f) Variabel Lingkungan $\left(\mathrm{X}_{2}\right)$ dengan indicator grup tatap muka tentang Keluarga sebagai refrensi $\left(\mathrm{X}_{2.6}\right)$ menunjukkan nilai 0,615 hal ini menunjukkan bahwa 61,5 persen varians dari Keluarga sebagai refrensi 
$\left(\mathrm{X}_{2.6}\right)$ dapat dijelaskan, oleh factor yang terbentuk (g) Variabel Lingkungan $\left(\mathrm{X}_{2}\right)$ dengan indicator grup tatap muka tentang Rekan kerja sebagai refrensi $\left(\mathrm{X}_{2.7}\right)$ menunjukkan nilai 0,618 hal ini menunjukkan bahwa 61,8 persen varians dari Rekan kerja sebagai refrensi $\left(\mathrm{X}_{2.7}\right)$ dapat dijelaskan, oleh factor yang terbentuk (h) Variabel Lingkungan $\left(\mathrm{X}_{2}\right)$ dengan indicator grup tatap muka tentang Rekan sekomunitas sebagai refrensi $\left(\mathrm{X}_{2.8}\right)$ menunjukkan nilai 0,590 hal ini menunjukkan bahwa 59,0 persen varians dari Rekan sekomunitas sebagai refrensi $\left(\mathrm{X}_{2.8}\right)$ dapat dijelaskan, oleh factor yang terbentuk (i) Variabel Lingkungan $\left(\mathrm{X}_{2}\right)$ dengan indicator situasional tentang Keripik singkong dibeli pada saat acara tertentu $\left(\mathrm{X}_{2.9}\right)$ menunjukkan nilai 0,650 hal ini menunjukkan bahwa 65,0 persen varians dari Keripik singkong dibeli pada saat acara tertentu $\left(\mathrm{X}_{2.9}\right)$ dapat dijelaskan, oleh factor yang terbentuk (j) Variabel Lingkungan $\left(X_{2}\right)$ dengan indicator situasional tentang Keripik singkong dibeli untuk oleh-oleh saat berlibur $\left(\mathrm{X}_{2.10}\right)$ menunjukkan nilai 0,605 hal ini menunjukkan bahwa 60,5 persen varians dari Keripik singkong dibeli untuk oleh-oleh saat berlibur $\left(\mathrm{X}_{2.10}\right)$ dapat dijelaskan, oleh factor yang terbentuk (k) Variabel Lingkungan $\left(\mathrm{X}_{2}\right)$ dengan indicator situasional tentang Pembelian keripik singkong diwaktu senja hari atau malam hari $\left(\mathrm{X}_{2.11}\right)$ menunjukkan nilai 0,571 hal ini menunjukkan bahwa 57,1 persen varians dari Pembelian keripik singkong diwaktu senja hari atau malam hari $\left(\mathrm{X}_{2.11}\right)$ dapat dijelaskan, oleh factor yang terbentuk (1) Variabel Lingkungan $\left(\mathrm{X}_{2}\right)$ dengan indicator situasional tentang Pembelian keripik singkong diwaktu pagi hari $\left(\mathrm{X}_{2.12}\right)$ menunjukkan nilai 0,677 hal ini menunjukkan bahwa 67,7 persen varians dari Pembelian keripik singkong diwaktu pagi hari $\left(\mathrm{X}_{2.12}\right)$ dapat dijelaskan, oleh factor yang terbentuk (m) Variabel Lingkungan $\left(\mathrm{X}_{2}\right)$ dengan indicator situasional tentang Pembelian keripik singkong dilakukan saat kondisi senang atau bahagia $\left(\mathrm{X}_{2.13}\right)$ menunjukkan nilai 0,450 hal ini menunjukkan bahwa 45,0 persen varians Pembelian keripik singkong dilakukan saat kondisi senang atau bahagia $\left(\mathrm{X}_{2.13}\right)$ dapat dijelaskan, oleh factor yang terbentuk (n) Variabel Lingkungan $\left(\mathrm{X}_{2}\right)$ dengan indicator situasional tentang Pembelian keripik singkong dilakukan saat kondisi sedih atau kecewa atau sakit hati $\left(\mathrm{X}_{2.14}\right)$ menunjukkan nilai 0,643 hal ini menunjukkan bahwa 64,3 persen varians dari Pembelian keripik singkong dilakukan saat kondisi sedih atau kecewa atau sakit hati $\left(\mathrm{X}_{2.14}\right)$ dapat dijelaskan, oleh factor yang terbentuk

Berdasarkan nilai pada tabel communalities bahwa variable-variabel yang ada dapat dijelaskan oleh factor yang terbentuk, semakin besar nilai communalities maka semain erat hubungannya dengan factor yang terbentuk. Untuk menentukan faktor yang terbentuk maka harus dilihat nilai eigenvaluenya harus berada diatas satu (1), jika kurang dari angka 1 maka tidak tepat. Berdasarkan tabel extraction method principal component analysis variable lingkungan hanya 4 faktor yang terbentuk, dimana 4 faktor menunjukkan angka diatas satu dan 10 faktor yang lain menunjukkan angka dibawah 1. Sehingga untuk variable individual terbatas hanya terdiri dari 4 faktor saja yaitu (a) Factor 1 dengan nilai 4,826 (b) Faktor 2 dengan nilai 1,482 (c) Factor 3 dengan nilai 1,222 (d) Factor 4 dengan nilai 1,042 
Tabel 5.76

Component Matrix ${ }^{\mathrm{a}}$

\begin{tabular}{|l|r|r|r|r|}
\hline & \multicolumn{4}{|c|}{ Component } \\
\cline { 2 - 5 } & \multicolumn{1}{|c|}{1} & \multicolumn{1}{|c|}{2} & \multicolumn{1}{c|}{3} & \multicolumn{1}{c|}{4} \\
\hline x2.1 &, 433 &, 560 &, 081 &,- 453 \\
x2.2 &, 458 &, 620 &,- 277 &, 037 \\
x2.3 &, 393 &, 481 &,- 159 &, 496 \\
x2.4 &, 698 &, 124 &,- 155 &, 320 \\
x2.5 &, 605 &,- 163 &, 254 &,- 268 \\
x2.6 &, 521 &, 154 &, 564 &, 039 \\
x2.7 &, 693 &, 137 &, 018 &,- 346 \\
x2.8 &, 642 &,- 144 &,- 190 &, 347 \\
x2.9 &, 729 &,- 077 &,- 111 &,- 317 \\
x2.10 &, 623 &,- 454 &,- 096 &, 032 \\
x2.11 &, 582 &,- 334 &, 323 &, 128 \\
x2.12 &, 525 &, 068 &, 554 &, 299 \\
x2.13 &, 528 &,- 260 &,- 302 &,- 111 \\
x2.14 &, 666 &,- 227 &,- 382 &,- 035 \\
\hline
\end{tabular}

Extraction Method: Principal Component Analysis.

a. 4 components extracted.

Dari hasil Principal Component Analysis. diatas dapat dianalisis (a) Pengaruh kebiasaan masyarakat $\left(\mathrm{X}_{2.1}\right)$ factor loading yang paling besar berada pada factor ke-2 dengan nilai 0,560 hal ini berarti Pengaruh kebiasaan masyarakat $\left(\mathrm{X}_{2.1}\right)$ berada pada factor ke-2 (b) Pengaruh tradisi masyarakat $\left(\mathrm{X}_{2.2}\right)$ factor loading yang paling besar berada pada factor ke-2 dengan nilai 0,620 hal ini berarti pengaruh tradisi masyarakat $\left(\mathrm{X}_{2.2}\right)$ berada pada factor ke-2 (c) Keripik singkong merupakan makanan camilan khas untuk kelas ekonomi menengah bawah $\left(\mathrm{X}_{2.3}\right)$ factor loading yang paling besar berada pada factor ke-4 dengan nilai 0,496 hal ini berarti Keripik singkong merupakan makanan camilan khas untuk kelas ekonomi menengah bawah $\left(\mathrm{X}_{2.3}\right)$ berada pada factor ke-4 (d) Keripik singkong merupakan makanan camilan khas untuk kelas ekonomi menengah atas $\left(\mathrm{X}_{2.4}\right)$ factor loading yang paling besar berada pada factor ke-1 dengan nilai 0,698 hal ini berarti Keripik singkong merupakan makanan camilan khas untuk kelas ekonomi menengah atas $\left(\mathrm{X}_{2.4}\right)$ berada pada factor $\mathrm{Ke}-1$ (e) Pengaruh kelas social lebih tinggi $\left(\mathrm{X}_{2.5}\right)$ factor loading yang paling besar berada pada factor ke-1 dengan nilai 0,605 hal ini berarti pengaruh kelas social lebih tinggi $\left(\mathrm{X}_{2.5}\right)$ berada pada factor ke-1 (f) Keluarga sebagai refrensi $\left(\mathrm{X}_{2.6}\right)$ factor loading yang paling besar berada pada factor ke-3 dengan nilai 0,564 hal ini berarti Keluarga sebagai refrensi $\left(\mathrm{X}_{2.6}\right)$ berada pada factor ke-3 (g) Rekan kerja sebagai refrensi $\left(\mathrm{X}_{2.7}\right)$ factor loading yang paling besar berada pada factor ke-3 dengan nilai 0,497 hal ini berarti Rekan kerja sebagai refrensi $\left(\mathrm{X}_{2.7}\right)$ berada pada factor (h) Rekan sekomunitas sebagai refrensi $\left(\mathrm{X}_{2.8}\right)$ factor loading yang paling besar berada pada factor ke-1 dengan nilai 0,642 hal ini berarti Rekan sekomunitas sebagai refrensi $\left(\mathrm{X}_{2.8}\right)$ berada pada factor ke-1 (i) Keripik singkong dibeli pada saat acara tertentu $\left(\mathrm{X}_{2.9}\right)$ factor loading yang paling besar berada pada factor ke-1 dengan nilai 0,729 hal ini berarti Keripik singkong dibeli pada saat acara tertentu $\left(\mathrm{X}_{2.9}\right)$ berada pada factor ke-1 (j) Keripik singkong dibeli untuk oleh-oleh saat berlibur $\left(\mathrm{X}_{2.10}\right)$ factor loading yang paling besar berada pada factor ke-1 dengan nilai 0,623 hal ini berarti Keripik singkong dibeli untuk oleh-oleh saat berlibur $\left(\mathrm{X}_{2.10}\right)$ berada pada factor ke-1 (k) Pembelian keripik singkong diwaktu senja hari atau malam hari $\left(\mathrm{X}_{2.11}\right)$ factor loading yang paling besar berada pada factor ke-1 dengan nilai 0,582 hal ini berarti Pembelian keripik singkong diwaktu senja hari atau malam hari $\left(\mathrm{X}_{2.11}\right)$ berada pada factor ke-1 (l) Pembelian keripik singkong diwaktu pagi hari $\left(\mathrm{X}_{2.12}\right)$ factor loading yang paling besar berada pada factor ke-3 dengan nilai 0,554 hal ini berarti Pembelian keripik singkong diwaktu pagi hari $\left(\mathrm{X}_{2.12}\right)$ berada pada factor ke-3 (m) Pembelian keripik singkong dilakukan saat kondisi senang atau bahagia $\left(\mathrm{X}_{2.13}\right)$ factor loading yang paling besar berada pada factor ke-1 dengan nilai 0,528 hal ini berarti Pembelian keripik singkong dilakukan saat kondisi senang atau bahagia $\left(\mathrm{X}_{2.13}\right)$ berada pada factor ke-1 
(n) Pembelian keripik singkong dilakukan saat kondisi sedih atau kecewa atau sakit hati $\left(\mathrm{X}_{2.14}\right)$ factor loading yang paling besar berada pada factor ke-1 dengan nilai 0,666 hal ini berarti Pembelian keripik singkong dilakukan saat kondisi sedih atau kecewa atau sakit hati $\left(\mathrm{X}_{2.14}\right)$ berada pada factor ke-1

Dari hasil penelitian dan analisis diatas dapat disimpulkan bahwa Faktor factor yang mempengaruhi konsumen dalam melakukan pembelian keripik singkong untuk variabel Lingkungan dikelompokkan menjadi 4 (empat) factor yaitu (1) Faktor 1 dinamakan factor budaya yang terdiri atas variabel $\mathrm{X}_{2.4}$ Makanan camilan kelas ekonomi menengah atas $(69,8 \%), \mathrm{X}_{2.5}$ Kelas social lebih tinggi $(60,5 \%), \mathrm{X}_{2.7}$ rekan kerja sebagai refrensi $(69,3 \%), \mathrm{X}_{2.8}$ Rekan sekomunitas sebagai refrens (64,2 \%), $\mathrm{X}_{2.9}$ Keripik singkong dibeli saat acara tertentu (72,9 \%), $\mathrm{X}_{2.10}$ Keripik singkong dibeli untuk oleholeh saat berlibur $(62,3 \%), \mathrm{X}_{2.11}$ pembelian keripik singkong diwaktu senja hari $(58,2 \%), \mathrm{X}_{2.12}$ pembelian keripik singkong diwaktu pagi hari $(52,5 \%), \quad \mathrm{X}_{2.13}$ pembelian keripik singkong saat kondisi senang (52,8\%), $\mathrm{X}_{2.14}$ pembelian keripik singkong saat kondisi sedih atau kecewa $(66,6 \%)(2)$ Faktor 2 dinamakan factor social yang terdiri atas variabel $\mathrm{X}_{2.1}$ Kebiasaan masyarakat $(56 \%)$ dan $\mathrm{X}_{2.2}$ Tradisi masyarakat (62\%) (3) Faktor 3 dinamakan factor grup tatap muka yang terdiri atas variabel $\mathrm{X}_{2.6}$ Keluarga sebagai refrensi $(56,4 \%)$ (4) Faktor 4 dinamakan factor situasional yang terdiri atas variabel $\mathrm{X}_{2.3}$ Makanan camilan kelas ekonomi menengah bawah $(49,6 \%)$

Variabel Marketing strategy (X3) Nilai KMO dan Bartlett Test untuk Variabel marketing strategy
Tabel 5.77

KMO and Bartlett's Test

Kaiser-Meyer-Olkin Measure of Sampling Adequacy.

Bartlett's Test of Sphericity

Approx. Chi-Square Df

Sig.

Dari tabel hasil nilai output , 000 diatas dapat dilihat bahwa nilai KMO dan Bartlett Test menunjukkan nilai 0,842 dengan tingkat signifikan 0,000 oleh sebab itu maka variable-variabel yang digunakan saling berkorelasi dan dapat dianalisis lebih lanjut

Tabel 5.78

Communalities

\begin{tabular}{|l|r|r|}
\hline & \multicolumn{1}{|c|}{ Initial } & \multicolumn{1}{|c|}{ Extraction } \\
\hline ×3.1 & 1,000 &, 469 \\
x3.2 & 1,000 &, 542 \\
×3.3 & 1,000 &, 711 \\
x3.4 & 1,000 &, 689 \\
x3.5 & 1,000 &, 660 \\
x3.6 & 1,000 &, 733 \\
x3.7 & 1,000 &, 723 \\
x3.8 & 1,000 &, 689 \\
x3.9 & 1,000 &, 632 \\
x3.10 & 1,000 &, 662 \\
x3.11 & 1,000 &, 625 \\
x3.12 & 1,000 &, 618 \\
x3.13 & 1,000 &, 558 \\
X3.14 & 1,000 &, 768 \\
\hline
\end{tabular}

Extraction Method: Principal Component Analysis.

Pada tabel diatas dapat dijelaskan bahwa (a) Variabel marketing strategy $\left(\mathrm{X}_{3}\right)$ dengan indicator produk tentang Keripik singkong memiliki cita rasa yang khas dan gurih $\left(\mathrm{X}_{3.1}\right)$ menunjukkan nilai 0,469 hal ini menunjukkan bahwa 46,9 persen varians dari Keripik singkong memiliki cita rasa yang khas dan gurih $\left(\mathrm{X}_{3.1}\right)$ dapat dijelaskan, oleh factor yang terbentuk (b) Variabel marketing strategy $\left(\mathrm{X}_{3}\right)$ dengan indicator produk tentang Keripik singkong merupakan makanan camilan yang tahan lama dan tidak mudah basi $\left(\mathrm{X}_{3.2}\right)$ menunjukkan nilai 0,542 hal ini menunjukkan bahwa 54,2 persen varians dari Keripik singkong merupakan makanan camilan yang tahan lama dan tidak mudah basi $\left(\mathrm{X}_{3.2}\right)$ dapat dijelaskan, oleh factor yang terbentuk (c) Variabel marketing strategy $\left(\mathrm{X}_{3}\right)$ dengan indicator produk tentang Tekstur keripik singkong gurih 
dan renyah $\left(\mathrm{X}_{3.3}\right)$ menunjukkan nilai 0,711 hal ini menunjukkan bahwa 71,1 persen varians dari Tekstur keripik singkong gurih dan renyah $\left(\mathrm{X}_{3.3}\right)$ dapat dijelaskan, oleh factor yang terbentuk (d) Variabel marketing strategy $\left(\mathrm{X}_{3}\right)$ dengan indicator produk tentang keripik singkong merupakan makanan camilan saat santai bersama keluarga atau teman $\left(\mathrm{X}_{3.4}\right)$ menunjukkan nilai 0,689 hal ini menunjukkan bahwa 68,9 persen varians dari keripik singkong merupakan makanan camilan saat santai bersama keluarga atau teman $\left(\mathrm{X}_{3.4}\right)$ dapat dijelaskan, oleh factor yang terbentuk (e) Variabel marketing strategy $\left(\mathrm{X}_{3}\right)$ dengan indicator produk tentang design produk (kemasan) yang menarik $\left(\mathrm{X}_{3.5}\right)$ menunjukkan nilai 0,660 hal ini menunjukkan bahwa 66,0 persen varians dari design produk (kemasan) yang menarik $\left(\mathrm{X}_{3.5}\right)$ dapat dijelaskan, oleh factor yang terbentuk (f) Variabel marketing strategy $\left(\mathrm{X}_{3}\right)$ dengan indicator produk tentang varian rasa yang ditawarkan berbedabeda $\left(\mathrm{X}_{3.6}\right)$ menunjukkan nilai 0,733 hal ini menunjukkan bahwa 73,3 persen varians dari varian rasa yang ditawarkan berbeda-beda $\left(\mathrm{X}_{3.6}\right)$ dapat dijelaskan, oleh factor yang terbentuk (g) Variabel marketing strategy $\left(\mathrm{X}_{3}\right)$ dengan indicator harga tentang harga sesuai pasaran $\left(\mathrm{X}_{3.7}\right)$ menunjukkan nilai 0,723 hal ini menunjukkan bahwa 72,3 persen varians dari harga sesuai pasaran $\left(\mathrm{X}_{3.7}\right)$ dapat dijelaskan, oleh factor yang terbentuk (h) Variabel marketing strategy $\left(\mathrm{X}_{3}\right)$ dengan indicator harga tentang harga murah dan terjangkau $\left(\mathrm{X}_{3.8}\right)$ menunjukkan nilai 0,689 hal ini menunjukkan bahwa 68,9 persen varians dari harga murah dan terjangkau $\left(\mathrm{X}_{3.8}\right)$ dapat dijelaskan, oleh factor yang terbentuk (i) Variabel marketing strategy $\left(\mathrm{X}_{3}\right)$ dengan indicator promosi tentang promosi dari mulut kemulut $\left(\mathrm{X}_{1.9}\right)$ menunjukkan nilai 0,632 hal ini menunjukkan bahwa 63,2 persen varians dari promosi dari mulut kemulut $\left(\mathrm{X}_{1.9}\right)$ dapat dijelaskan, oleh factor yang terbentuk (j) Variabel marketing strategy $\left(\mathrm{X}_{3}\right)$ dengan indicator promosi tentang promosi dilakukan melalui $\mathrm{TV}$ radio dll $\left(\mathrm{X}_{1.10}\right)$ menunjukkan nilai 0,662 hal ini menunjukkan bahwa 66,2 persen varians dari promosi dilakukan melalui TV radio dll $\left(\mathrm{X}_{1.10}\right)$ dapat dijelaskan, oleh factor yang terbentuk (k) Variabel marketing strategy $\left(\mathrm{X}_{3}\right)$ dengan indicator promosi tentang promosi secara online $\left(\mathrm{X}_{3.11}\right)$ menunjukkan nilai 0,625 hal ini menunjukkan bahwa 62,5 persen varians dari promosi secara online $\left(\mathrm{X}_{3.11}\right)$ dapat dijelaskan, oleh factor yang terbentuk (1) Variabel marketing strategy $\left(\mathrm{X}_{3}\right)$ dengan indicator tempat tentang keripik mudah diperoleh $\left(\mathrm{X}_{3.12}\right)$ menunjukkan nilai 0,618 hal ini menunjukkan bahwa 61,8 persen varians dari keripik singkong mudah diperoleh $\left(\mathrm{X}_{3.12}\right)$ dapat dijelaskan, oleh factor yang terbentuk (m) Variabel marketing strategy $\left(\mathrm{X}_{3}\right)$ dengan indicator tempat tentang lokasi penjualan dekat dengan rumah $\left(\mathrm{X}_{3.13}\right)$ menunjukkan nilai 0,558 hal ini menunjukkan bahwa 55,8 persen varians dari lokasi penjualan dekat dengan rumah $\left(\mathrm{X}_{3.13}\right)$ dapat dijelaskan, oleh factor yang terbentuk (n) Variabel marketing strategy $\left(\mathrm{X}_{3}\right)$ dengan indicator tempat tentang pembelian dilakukan ditempat lain karena harga yang ditawarkan lebih murah $\left(\mathrm{X}_{3.14}\right)$ menunjukkan nilai 0,768 hal ini menunjukkan bahwa 76,8 persen varians dari pembelian dilakukan ditempat lain karena harga yang ditawarkan lebih murah $\left(\mathrm{X}_{3.14}\right)$ dapat dijelakan oleh factor yang terbentuk

Berdasarkan nilai pada tabel communalities bahwa variable-variabel yang ada dapat dijelaskan oleh factor yang terbentuk, semakin besar nilai communalities maka semain erat hubungannya dengan factor yang terbentuk. Untuk menentukan faktor yang terbentuk maka harus dilihat nilai 
eigenvaluenya harus berada diatas satu (1), jika kurang dari angka 1 maka tidak tepat. Berdasarkan tabel extraction method principal component analysis variable marketing strategy hanya 3 faktor yang terbentuk, dimana 3 faktor menunjukkan angka diatas satu dan 14 faktor yang lain menunjukkan angka dibawah 1. Sehingga untuk variable mareting strategy terbatas hanya terdiri dari 3 faktor saja (a) Factor 1 dengan nilai 6,017 (b) Faktor 2 dengan nilai 1,924 (c) Factor 3 dengan nilai 1,137

Setelah diketahui bahwa 3 faktor adalah jumlah yang paling optimal, maka component matriks menunjukkan distribusi ke 14 faktor tersebut ke 3 faktor yang terbentuk, sedangkan angka-angka yang ada pada tabel tersebut adalah factor loading, proses penentuan variable mana yang akan masuk ke factor mana, dilakukan perbandingan besar korelasi setiap baris

Tabel 5.80

Component Matrix ${ }^{a}$

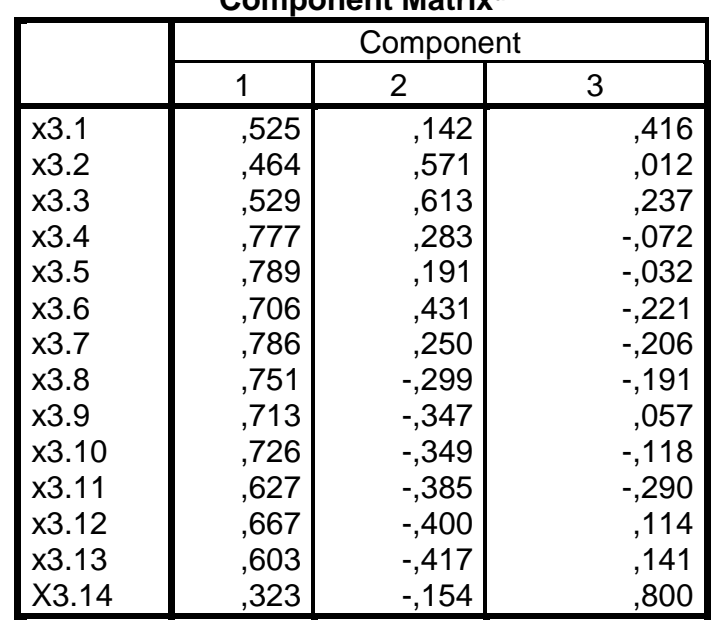

Extraction Method: Principal Component Analysis.

a. 3 components extracted.

Dari hasil Principal

Component Analysis. diatas dapat dianalisis (a) Keripik singkong memiliki cita rasa yang khas dan gurih $\left(\mathrm{X}_{3.1}\right)$ factor loading yang paling besar berada pada factor ke-1 dengan nilai 0,525 hal ini berarti Keripik singkong memiliki cita rasa yang khas dan gurih
$\left(\mathrm{X}_{3.1}\right)$ berada pada factor ke-1 (b) Keripik singkong merupakan makanan camilan yang tahan lama dan tidak mudah basi $\left(\mathrm{X}_{3.2}\right)$ factor loading yang paling besar berada pada factor ke-2 dengan nilai 0,571 hal ini berarti Keripik singkong merupakan makanan camilan yang tahan lama dan tidak mudah basi $\left(\mathrm{X}_{3.2}\right)$ berada pada factor ke-2 (c) Tekstur keripik singkong gurih dan renyah $\left(\mathrm{X}_{3.3}\right)$ factor loading yang paling besar berada pada factor ke-2 dengan nilai 0,613 hal ini berarti Tekstur keripik singkong gurih dan renyah $\left(\mathrm{X}_{3.3}\right)$ berada pada factor ke-2 (d) keripik singkong merupakan makanan camilan saat santai bersama keluarga atau teman $\left(\mathrm{X}_{3.4}\right)$ factor loading yang paling besar berada pada factor ke-1 dengan nilai 0,777 hal ini berarti keripik singkong merupakan makanan camilan saat santai bersama keluarga atau teman $\left(\mathrm{X}_{3.4}\right)$ berada pada factor $\mathrm{Ke}-1$ (e) design produk (kemasan) yang menarik $\left(\mathrm{X}_{3.5}\right)$ factor loading yang paling besar berada pada factor ke-1 dengan nilai 0,789 hal ini berarti design produk (kemasan) yang menarik $\left(\mathrm{X}_{3.5}\right)$ berada pada factor ke-1 (f) varian rasa yang ditawarkan berbeda-beda $\left(\mathrm{X}_{3.6}\right)$ factor loading yang paling besar berada pada factor ke-1 dengan nilai 0,706 hal ini berarti varian rasa yang ditawarkan berbedabeda $\left(\mathrm{X}_{3.6}\right)$ berada pada factor ke-1 $(\mathrm{g})$ Harga sesuai pasaran $\left(\mathrm{X}_{3.7}\right)$ factor loading yang paling besar berada pada factor ke-1 dengan nilai 0,786 hal ini berarti Harga sesuai pasaran $\left(\mathrm{X}_{3.7}\right)$ berada pada factor ke-1 (h) Harga murah dan terjangkau $\left(\mathrm{X}_{3.8}\right)$ factor loading yang paling besar berada pada factor ke-1 dengan nilai 0,751 hal ini berarti Harga murah dan terjangkau $\left(\mathrm{X}_{3.8}\right)$ berada pada factor ke-1 (i) Promosi dari mulut kemulut $\left(\mathrm{X}_{1.9}\right)$ factor loading yang paling besar berada pada factor ke-1 dengan nilai 0,713 hal ini berarti Promosi dari mulut kemulut $\left(\mathrm{X}_{1.9}\right)$ berada pada factor ke-1 (j) promosi dilakukan melalui $\mathrm{TV}$ 
radio dll $\left(\mathrm{X}_{1.10}\right)$ factor loading yang paling besar berada pada factor ke-1 dengan nilai 0,726 hal ini berarti promosi dilakukan melalui $\mathrm{TV}$ radio dll $\left(\mathrm{X}_{1.10}\right)$ berada pada factor ke-1 $(\mathrm{k})$ promosi secara online $\left(\mathrm{X}_{3.11}\right)$ factor loading yang paling besar berada pada factor ke-1 dengan nilai 0,627 hal ini berarti promosi secara online $\left(\mathrm{X}_{3.11}\right)$ berada pada factor ke-1 (l) keripik mudah diperoleh $\left(\mathrm{X}_{3.12}\right)$ factor loading yang paling besar berada pada factor ke-1 dengan nilai 0,667 hal ini berarti keripik mudah diperoleh $\left(\mathrm{X}_{3.12}\right)$ berada pada factor ke-1 (m) lokasi penjualan dekat dengan rumah $\left(\mathrm{X}_{3.13}\right)$ factor loading yang paling besar berada pada factor ke-1 dengan nilai 0,603 hal ini berarti lokasi penjualan dekat dengan rumah $\left(\mathrm{X}_{3.13}\right)$ berada pada factor ke-1 (n) pembelian dilakukan ditempat lain karena harga yang ditawarkan lebih murah $\left(\mathrm{X}_{3.14}\right)$ factor loading yang paling besar berada pada factor ke-3 dengan nilai 0,800 hal ini berarti pembelian dilakukan ditempat lain karena harga yang ditawarkan lebih murah $\left(\mathrm{X}_{3.14}\right)$ berada pada factor ke-3

Dari hasil penelitian dan analisis diatas dapat disimpulkan bahwa Faktor factor yang mempengaruhi konsumen dalam melakukan pembelian keripik singkong untuk variabel Marketing startegy dikelompokkan menjadi 3 (Tiga) factor yaitu (1) Faktor 1 dinamakan factor promosi yang terdiri atas beberapa variabel yaitu $X_{3.1}$ keripik singkong memiliki cita rasa yang khas dan gurih $(52,5 \%), \mathrm{X}_{3.4}$ Makanan camilan saat santai bersama keluarga $(77,7 \%), \mathrm{X}_{3.5} \quad$ Desaign produk menarik $(78,9 \%), \mathrm{X}_{3.6}$ Varian rasa yang ditawarkan berbeda-beda $(70,6 \%), X_{3.7}$ Harga sesuai pasaran $(78,6 \%), \mathrm{X}_{3.8}$ Harga murah dan terjangkau $(75,1 \%), \mathrm{X}_{3.9}$ promosi dari mulut ke mulut $(71,3 \%), X_{3.10}$ promosi dilakukan melalui $\mathrm{TV}$ dan radio $(72,6$ $\%), \mathrm{X}_{3.11}$ promosi secara online $(62,7$ $\%), \mathrm{X}_{3.12}$ keripik mudah diperoleh
$(66,7 \%), X_{3.13}$ lokasi penjualan dekat dengan rumah $(60,3 \%)$ (2) Faktor 2 dinamakan factor terdiri dari $\mathrm{X}_{3.2}$ Camilan tahan lama dan tidak mudah basi $(57,1 \%)$ dan $\mathrm{X}_{3.3}$ Tekstur keripik singkong gurih dan renyah $(61,3 \%)$ (3 )Faktor 3 dinamakan factor distribusi yang terdiri dari variabel $\mathrm{X}_{3.14}$ pembelian dilakukan ditempat lain karena harga yang ditawarkan lebih murah $(80 \%)$

Dari hasil penelitian dapat diketahui bahwa variabel individual, lingkungan dan marketing strategy sangat mempengaruhi konsumen. Berdasarkan penelitian diatas factor factor yang paling dominan dengan melihat total nilai varians pada total variance explained secara keseluruhan dan berurutan adalah (1) Factor harga dan promosi yang merupakan factor yang paling dominan dengan nilai varians terbesar yaitu 42,981\% (2) Faktor situasional yang merupakan bagian penting dalam proses pembelian dengan nilai varians 34,474 $\%$ (3) Factor persepsi merk dengan nilai varians $30,737 \%$ (4) produk dengan nilai varians $13,746 \%$ (5) Factor budaya dengan nilai varians $13,746 \%$ (6) Factor gaya hidup dengan nilai varians $10,169 \%$ (7) Factor grup tatap muka dengan nilai varians $8,730 \%$ (8) Factor place dengan nilai varians $8,122 \% \quad$ (9) Factor situasional dengan nilai varians $7,442 \%$ (10) Factor demografi konsumen dengan nilai varians 7,120 $\%$ (11) Factor personalia dengan nilai varians 6,968 \% (12) Factor kebutuhan dan keinginan dengan nilai varians $6,030 \%$

Faktor promosi menjadi factor utama dan paling dominan dengan nilai varians terbesar $(42,981 \%)$ dalam penelitian ini karena harga yang ditawarkan oleh keripik singkong murah dan dapat dijangkau oleh masyarakat, sehingga keripik menjadi pilihan makanan camilan saat santai bersama keluarga karena harganya 
yang murah dan isi dari keripik banyak selain harga promosi yang dilakukan gencar, sehingga promosi yang dilakukan oleh perusahaan mampu mempengaruhi konsumen, keripik mudah diperoleh karena hampir terdapat di seluruh desa sehingga konsumen mampu untuk menjangkau, rasa yang ditawarkan keripik yang memiliki citarasa yang khas mampu menjadi daya tarik konsumen

Faktor situasional menjadi bagian penting dalam proses pembelian keripik singkong dalam penelitian ini karena situasi dimana keripik banyak dijadikan masyarakat untuk hidangan pada saat acara-acara tertentu seperti nikahnan, khitan, tahlil atau istigosah, dimana setelah acara selesai masyarakat memilih untuk nyemil dan yang dipilih adalah keripik singkong, selain keripik singkong tahan lam, juga tidak mudah basi, tidak bosan dan banyak konsumen yang memilih keripik singkong

Faktor persepsi merk menjadi faktor yang berperan dominan dalam penelitian ini dengan nilai varians $(30,737 \%)$, masyarakat atau konsumen melakukan suatu pembelian karena merk meiliki peranan penting karena merk berhubungan dengan kualitas produk, masyarakat memilih keripik dengan kualitas yang bagus. Varian rasa yang ditawarkan berbedabeda sehinga masyarakat tidak jenuh dan bosan, desaign produk yang menarik akan menarik konsumen untuk melakukan suatu pembelian, cita rasa yang khas dan gurih, tidak mudah basi dan tahan lama menjadi daya tarik konsumen sehingga persepsi merk akan mempengaruhi pembelian, persepsi merk di mata masyarakat adalah merk itu memiliki nilai positif dimata masyrakat dan produknya mampu memuaskan konsumen mampu memenuhi kebutuhan konsumen.

KESIMPULAN DAN SARAN

\section{Kesimpulan}

Berdasarkan hasil penelitian yang sudah dilakukan dapat ditarik kesimpulan sebagai berikut (1) Berdasarkan hasil penelitian factor faktor yang mempengaruhi konsumen dalam pembelian keripik singkong adalah sebagai berikut (a) untuk variabel individual dikelompokkan menjadi 5 (Lima) factor yaitu (1) Faktor 1 persepsi merk terdiri atas beberapa variabel yaitu $\mathrm{X}_{1.2}$ pembelian keripik singkong berdasarkan merkmerk tertentu (45,5 \%), $\mathrm{X}_{1.3}$ merk sudah dikenal konsumen $(70,8 \%), \mathrm{X}_{1.4}$ kepercayaan terhadap merk $(51,6 \%)$, $\mathrm{X}_{1.5}$ merk berkualitas $(48,1 \%), \mathrm{X}_{1.8}$ perbedaan profesi $(54,3 \%), \mathrm{X}_{1.10}$ konsumen berpendapatan tinggi $(57,5$ $\%), \mathrm{X}_{1.11}$ konsumen berpendidikan tinggi $(66,3 \%), \quad \mathrm{X}_{1.13}$ konsumen beragama islam $(61,1 \%), \quad \mathrm{X}_{1.14}$ pengalaman konsumen $(73 \%), \mathrm{X}_{1.16}$ Dorongan diri dalam mengkonsumsi keripik singkong $(67,5 \%), \mathrm{X}_{1.7}$ gaya hidup sehat $(70,7 \%), \mathrm{X}_{1.18}$ gaya hidup modern ( $62,6 \%)$, dan $X_{1.19}$ gaya hidup hemat ( $55,2 \%$ ) (2) Faktor 2 gaya hidup terdiri atas dua variabel yaitu $\mathrm{X}_{1.9}$ konsumen berpendapatan rendah $(55,6 \%)$ dan $X_{1.15}$ keinginan pribadi $(63,3)$ (3) Faktor 3 demografi terdiri atas dua variabel yaitu $\mathrm{X}_{1.6}$ usia konsumen $(48,6 \%)$ dan $\mathrm{X}_{1.12}$ Konsumen berpendidikan rendah (57 \%) (4) Faktor 4 personalia terdiri atas variabel $\mathrm{X}_{1.7}$ status konsumen (51,5 $\%$ ) (5) Faktor 5 kebutuhan dan keinginan konsumen terdiri atas variabel $\mathrm{X}_{1.1}$ kebutuhan dan keinginan konsumen $(76,9 \%)$ (b) untuk variabel Lingkungan dikelompokkan menjadi 4 (empat) factor yaitu (1) Faktor 1 situasional terdiri atas variabel $\mathrm{X}_{2.4}$ Makanan camilan kelas ekonomi menengah atas $(69,8 \%), \mathrm{X}_{2.5}$ Kelas social lebih tinggi $(60,5 \%), \mathrm{X}_{2.7}$ rekan kerja sebagai refrensi $(69,3 \%), \mathrm{X}_{2.8}$ Rekan sekomunitas sebagai refrens $(64,2 \%), X_{2.9}$ Keripik singkong dibeli 
saat acara tertentu $(72,9 \%), \quad \mathrm{X}_{2.10}$ Keripik singkong dibeli untuk oleholeh saat berlibur $(62,3 \%), \mathrm{X}_{2.11}$ pembelian keripik singkong diwaktu senja hari $(58,2 \%), \mathrm{X}_{2.12}$ pembelian keripik singkong diwaktu pagi hari $(52,5 \%), \quad X_{2.13}$ pembelian keripik singkong saat kondisi senang (52,8 \%), $\mathrm{X}_{2.14}$ pembelian keripik singkong saat kondisi sedih atau kecewa $(66,6 \%)(2)$ Faktor 2 budaya terdiri atas variabel $\mathrm{X}_{2.1}$ Kebiasaan masyarakat (56\%) dan $\mathrm{X}_{2.2}$ Tradisi masyarakat (62\%) (3) Faktor 3 grup tatap muka terdiri atas variabel $\mathrm{X}_{2.6}$ Keluarga sebagai refrensi $(56,4 \%)$ (4) Faktor 4 sosial terdiri atas variabel $\mathrm{X}_{2.3}$ Makanan camilan kelas ekonomi menengah bawah $(49,6 \%)$ (c) untuk variabel Marketing startegy dikelompokkan menjadi 3 (Tiga) factor yaitu (1) Faktor 1 promosi terdiri atas beberapa variabel yaitu $\mathrm{X}_{3.1}$ keripik singkong memiliki cita rasa yang khas dan gurih (52,5 \%), $\mathrm{X}_{3.4}$ Makanan camilan saat santai bersama keluarga $(77,7 \%), \mathrm{X}_{3.5} \quad$ Desaign produk menarik $(78,9 \%), \mathrm{X}_{3.6}$ Varian rasa yang ditawarkan berbeda-beda $(70,6$ $\%), \mathrm{X}_{3.7}$ Harga sesuai pasaran $(78,6$ $\%), \mathrm{X}_{3.8}$ Harga murah dan terjangkau $(75,1 \%), \mathrm{X}_{3.9}$ promosi dari mulut ke mulut $(71,3 \%), \quad \mathrm{X}_{3.10}$ promosi dilakukan melalui $\mathrm{TV}$ dan radio $(72,6$ $\%), \mathrm{X}_{3.11}$ promosi secara online $(62,7$ $\%), \mathrm{X}_{3.12}$ keripik mudah diperoleh $(66,7 \%), \mathrm{X}_{3.13}$ lokasi penjualan dekat dengan rumah $(60,3 \%)$ (2) Faktor 2 produk terdiri dari $\mathrm{X}_{3.2}$ Camilan tahan lama dan tidak mudah basi $(57,1 \%)$ dan $X_{3.3}$ Tekstur keripik singkong gurih dan renyah $(61,3 \%)$ (3) Faktor 3 distribusi terdiri dari variabel $\mathrm{X}_{3.14}$ pembelian dilakukan ditempat lain karena harga yang ditawarkan lebih murah $(80 \%)$. Dari hasil penelitian diatas faktor harga dan promosi menjadi factor utama dan paling dominan dengan nilai varians terbesar $(42,981 \%)$ dalam penelitian ini karena harga yang ditawarkan oleh keripik singkong murah dan dapat dijangkau oleh masyarakat, promosi yang dilakukan gencar, sehingga promosi yang dilakukan oleh perusahaan mampu mempengaruhi konsumen, keripik mudah diperoleh karena hampir terdapat di seluruh desa sehingga konsumen mampu untuk menjangkau, rasa yang ditawarkan keripik yang memiliki citarasa yang khas mampu menjadi daya tarik konsumen Faktor situasional karena situasi dimana keripik banyak dijadikan masyarakat untuk hidangan pada saat acara-acara tertentu seperti nikahan, khitan, tahlil atau istigosah lebih memilih keripik singkong karena tahan lama, juga tidak mudah basi, tidak bosan dan banyak konsumen yang memilih keripik singkong . Faktor persepsi merk menjadi faktor yang berperan dominan dalam penelitian ini karena merk berhubungan dengan kualitas produk, masyarakat memilih keripik dengan kualitas yang bagus. persepsi merk di mata masyarakat adalah merk itu memiliki nilai positif dimata masyrakat dan produknya mampu memuaskan konsumen mampu memenuhi kebutuhan konsumen.(2) penitian ini sangat bermanfaat bagi para peneliti, karena mempelajari atau melakukan suatu penelitian terhadap prilaku konsumen perlu dan penting terutama bagi perusahaan karena dengan mengetahui prilaku konsumen maka kita mengetahui sikap atau fakta tentang konsumen, perusahaan atau peneliti mengetahui kebutuhan dan keinginan apa yang diinginkan oleh masyarakat yang akhirnya dapat diterapkan oleh perusahaan dalam menyusun konsep pemasaran, strategi pemasaran, kunci keberhasilan perusahaan terdapat pada konsumen. Maka perusahaan perlu melakukan analisis tentang prilaku konsumen yang selalu berbeda setiap saat.

Saran 
Saran yang dapat diberikan oleh peneliti adalah (1) bagi peneliti selanjutnya diharapkan untuk melakukan penelitian dengan memasukkan sub variabel inovasi produk pada variabel marketing strategy yang belum dilakukan oleh peneliti sebelumnya (2) bagi masyrakat diharapkan penelitian ini dapat menjadi acuan dalam melakukan bisnis atau wirausaha dalam menentukan apa saja factor-faktor yang mempengaruhi konsumen dalam menentukan keputusan pembelian, dengan mengetahui itu maka masyrakat dapat meningkatkan pelayanan konsumen

\section{DAFTAR PUSTAKA}

Abdullah T dan Tantri F. 2012. Manajemen Pemasaran. Jakarta: PT Rajagrafindo Persada

Badan Litbang Pertanian. 2011. Inovasi Pengolahan Singkong Meningkatkan Pendapatan dan Diversifikasi Pangan. Jurnal Agroinovasi Edisi 4-10 Mei 2011 No.3404 Tahun XLI

Badan Pusat Statistika (BPS). 2015. Produksi Ubi kayu Menurut Provinsi (ton), 19932015.(https://www.bps.go.id/lin kTableDinamis/view/id/880.ht ml) Diakses tanggal 14 Oktober 2016.

Ghozali I. 2013. Aplikasi Analisis Multivariate dengan Program IBM SPSS 21. Semarang: Badan Penerbit Universitas Diponegoro.

Kotler P dan Keller KL. 2009. Manajemen Pemasaran (Ed. 13) jilid 1. Jakarta: Erlangga
Sarjono H dan Julianita W. 2011. SPSS vs LISREL Sebuah Pengantar, Aplikasi untuk Riset. Jakarta: Salemba Empat

Shabastian M dan Samuel H. 2013. Pengaruh Strategi Harga dan Strategi Produk Terhadap Brand Loyalty di Tator Cafe Surabaya Town Square. Jurnal Manajemen Pemasaran Vol. 1, No. 1, (2013) 1-9. Surabaya: Universitas Kristen Petra

Suardika P, Ambarawati, Sukaatmadja. 2014. Analisis Perilaku Konsumen terhadap Keputusan Pembelian Sayur Organik CV Golden Leaf Farm Bali. Jurnal Manajemen Agribisnis Vol.2, No. 1. Bali: Universitas Udayana

Sugiyono. 2012. Statistika Untuk Penelitian (Ed. 21). Bandung: Alfabeta

Umikalsum. 2015. Strategi Pemasaran Usaha Industri Keripik Singkong Skala Rumah Tangga di Kelurahan Tangga Takat Kecamatan Seberang Ulu II Kota Palembang. Jurnal Ilmiah AgrIBA Vol. 3 No. 1 Edisi 3. Palembang: IBA

Wardana LW. 2011. Perilaku Konsumen (Ed. 1). Malang: Universitas Negeri Gorontalo Press 
